\title{
PENGARUH RASIO PROFITABILITAS DAN LIKUIDITAS TERHADAP HARGA SAHAM PERUSAHAAN PADA SEKTOR PROPERTY
}

\section{THE EFFECT OF PROFITABILITY AND LIQUIDITY RATIOS ON COMPANY SHARE PRICES IN THE PROPERTY SECTOR}

\author{
Rafida Khairani ${ }^{1}$, Fati Syafira ${ }^{2}$, Masnika Sinaga ${ }^{3}$, \\ Roryn Chelsi Gea ${ }^{4}$, Lorensisca Sitorus ${ }^{5}$ \\ Universitas Prima Indonesia Medan 1,2,3,4,5 \\ $\underline{\text { Rafidakhairani256@gmail.com }}{ }^{1}$
}

\begin{abstract}
The purpose of this research is to analyze the effect of profitability and Liqudity on the company's stock price in Property Sector. This research uses a quantitative approach, the type of research used is associative research. The data used are secondary data in the form of company financial statements obtained from the Indonesia Stock Exchange (IDX). In determining the sample of this study using a purposive sampling method that is determining the sample by making certain criteria. The data analysis method uses multiple linear regression analysis. Testing the hypothesis in this study using the test to determine the effect of individual independent variables on the dependent variable. While the F test is used to determine the effect of Current Ratio (CR), Net Profit Margin (NPM), Return On Assets (ROA) simultaneously on stock prices. The regresion results of this research shows that independent variables like $C R$ and $R O A$ has a positive effect in predicting stock prices. While, the NPM variable has a negative effect in predicting the stock prices. Current Ratio (CR), Net Profit Margin (NPM), and Return On Assets (ROA) simultaneously have a significant effect on Stock Prices. Partially, Current Ratio (CR), and Return On Assets (ROA) have a significant effect on Stock Prices. While Net Profit Margin (NPM) Does not have significant effect on Stock Prices. From the regression coefficient test concluded that $58,8 \%$ of the share price can be explained by the independent variables
\end{abstract}

Keywords: Profitability, Liquidity, Stock Prices.

\begin{abstract}
ABSTRAK
Tujuan penelitian ini adalah untuk menganalisis pengaruh Rasio profitabilitas dan Likuiditas terhadap harga saham perusahaan pada sektor Property. Penelitian ini menggunakan pendekatan kuantitatif. Data yang digunakan adalah data sekunder berupa laporan keuangan perusahaan yang diperoleh dari Bursa Efek Indonesia (BEI). Dalam penentuan sampel penelitian ini menggunakan metode purposive sampling yaitu menentukan sampel dengan membuat kriteria tertentu. Metode analisis data menggunakan analisis regresi linear berganda. Pengujian hipotesis dalam penelitian ini mengunakan uji t untuk mengetahui pengaruh variabel independen secara individu terhadap variabel dependen. Sedangkan uji F digunakan untuk mengetahui pengaruh Current Ratio (CR), Net Profit Margin (NPM), Return On Asset (ROA). Hasil regresi dari penelitian ini menunjukkan bahwa variabel bebas yaitu $C R$ dan ROA berhubungan secara positif dalam memprediksi Harga Saham. Sedangkan variabel NPM berhubungan negatif dalam memprediksi Harga Saham. Current Ratio (CR), Net Profit
\end{abstract}


Margin (NPM), dan Return On Assets (ROA) secara simultan berpengaruh signifikan terhadap harga saham. Secara parsial, Current Ratio (CR), dan Return On Asset (ROA) berpengaruh signifikan terhadap harga saham. Sedangkan variabel Net Profit Margin $(N P M)$ tidak berpengaruh signifikan terhadap Harga Saham. Dari uji koefisien regresi disimpulkan 58,8\% dari harga saham dapat dijelaskan oleh variabel-variabel independen.

Kata Kunci: Profitabilitas, Likuiditas, Harga Saham

\section{PENDAHULUAN}

Kehadiran pasar modal di Indonesia ditandai dengan banyaknya investor yang mulai menanamkan sahamnya dalam industri real estate and property. Bisnis real estate and property baik residensial maupun komersial menunjukkan perkembangan yang cukup pesat di Indonesia. Semakin pesatnya perkembangan sektor properti ini diikuti dengan semakin tingginya permintaan akan kebutuhan papan, sehingga membuat emiten-emiten properti membutuhkan dana dari sumber eksternal. Dana dari sumber eksternal dapat diperoleh melalui pasar modal (Kurnia et al. 2018). Sesuai dengan tujuan yang hendak dicapai, terdapat beberapa jenis rasio profitabilitas yang dapat digunakan. Masing-masing jenis rasio profitabilitas digunakan untuk menilai serta mengukur posisi keuangan perusahaan dalam satu periode tertentu atau untuk beberapa periode. Penggunaan seluruh atau sebagian rasio profitabilitas tergantung dari kebijakan manajemen. Jelasnya, semakin lengkap jenis rasio yang digunakan, semakin sempurna hasil yang akan dicapai. Artinya pengetahuan tentang kondisi dan posisi profitabilitas perusahaan dapat diketahui secara sempurna (Monterroso 2015) Rasio Profitabilitas yang digunakan dalam penelitian ini adalah Return On Assets (ROA) dan Net Profit Margin (NPM) karena kedua rasio ini yang paling sering digunakan investor dalam mengukur posisi keuangan perusahaan.

Likuiditas merupakan salah satu faktor yang yang dapat mendorong terjadi perubahan harga saham. Likuiditas tinggi menunjukan kemampuan perusahaan dalam memenuhi kewajiban jangka pendeknya. Likuiditas perusahaan dapat diukur dengan rasio lancar, Rasio lancar menunjukan kemampuan perusahaan untuk membayar utang lancar dengan menggunakan aktiva lancar yang dimiliki (Syaiful, 2013), sehingga penulis memilih Current Ratio untuk diteliti dari rasio likuiditas karena rasio ini sangat berguna bagi investor karena dapat menunjukan kemampuan perusahaan dalam membayar hutang.

Current ratio (rasio lancar) adalah ukuran yang umum digunakan atas solvensi jangka pendek, kemampuan suatu perusahaan memenuhi kebutuhan utang perusahaan ketika jatuh tempo. Harus dipahami bahwa penggunaan current ratio dalam menganalisis laporan keuangan hanya mampu memberikan analisa secara kasar, oleh karena itu perlu adanya dukungan analisa secara kualitatif secara komprehensif. Current Ratio yang tinggi akan menimbulkan kepercayaan investor untuk menginvestasikan modalnya ke perusahaan. Karena perusahaan dinilai memiliki kemampuan untuk melunasi kewajiban-kewajiban jangka pendeknya, sehingga dapat 
meningkatkan permintaan saham perusahaan tersebut (Febrioni, 2016).

Net Profit Margin (NPM) merupakan rasio yang menunjukkan seberapa besar persentase laba bersih yang diperoleh dari setiap penjualan Rasio ini menginterpretasikan tingkat efisiensi perusahaan, yakni sejauh mana kemampu- an perusahaan menekan biaya-biaya operasionalnya pada periode tertentu. Semakin besar rasio ini semakin baik karena kemampuan perusahaan dalam mendapatkan laba melalui penjualan cukup tinggi serta kemampuan perusahaan dalam menekan biaya-biayanya cukup baik. Sebaliknya (Hutami 2012).

Return On Asset merupakan salah satu bentuk rasio profitabilitas yang dimaksudkan untuk mengukur kemampuan perusahaan atas keseluruhan dana yang ditanamkan dalam aktivitas yang digunakan untuk aktivitas operasi perusahaan dengan tujuan menghasilkan laba dengan memanfaatkan aktiva yang dimilikinya (Febrioni 2016).

Harga saham merupakan harga yang dibentuk dari interaksi para penjual dan pembeli saham yang dilatarbelakangi oleh harapan terhadap profit perusahaan. Dalam aktivitas di pasar modal, harga saham merupakan faktor yang sangat penting dan harus diperhatikan oleh investor dalam melaksanakan investasi, karena harga saham menunjukkan nilai suatu perusahaan. Semakin tinggi nilai harga saham semakin tinggi pula nilai perusahaan tersebut dan juga sebaliknya. Harga saham di bursa ditentukan oleh kekuatan pasar, yang berarti harga saham tergantung dari kekuatan permintaan dan penawaran (Christine, 2012).

Pada hasil penelitian Ramdhani (2013) Return on Asset dan Debt to Equity Ratio tidak memiliki pengaruh yang signifikan terhadap Harga Saham. Sedangkan menurut (Tewal \& Jan 2017) ROA dan NPM berpengaruh signifikan terhadap Harga Saham. Menurut hasil Darnita (2012) Secara parsial dengan uji t disimpulkan bahwa secara parsial variabel ROA dan EPS tidak berpengaruh secara signifikan terhadap harga saham. Menurut hasil Febrioni (2016) Current Ratio (CR) tidak berpengaruh signifikan terhadap return saham dengan arah pengaruh yang negatif pada perusahaan yang terdaftar Indeks LQ45 di Bursa Efek Indonesia periode 2011-2015. Sedangkan menurut penelitian Deitiana (2013) Tidak ada pengaruh current ratio, total asset turn over dan dividend payout ratio terhadap harga saham. Dengan demikian dapat disimpulkan bahwa Return on Assets, Net Profit Margin dan Current Ratio dapatmembantu para investor untuk mengevaluasi pertumbuhan harga saham masa lalu untuk memprediksikan harga saham yang akan datang.

Penelitian oleh Deitiana, (2013) Pengamatan yang diambil adalah periode 2008-2011. Penelitian ini menggunakan analisa jalur yang memberikan hasil bahwa perputaran total aset berpengaruh terhadap rasio pembayaran dividen. Sedangkan return on equity berpengaruh terhadap harga saham. Hasil penelitian menunjukkan bahwa fundamental perusahaan, yakni aspek keuangan menjadi pertimbangan untuk pembayaran dividen dan berimplikasi pada harga saham.

Penelitian oleh Ortecho, (2011), Hasil penelitian menunjukkan bahwa secara serempak (bersama-sama) variabel Net Profit Margin (NPM), Return On Assets (ROA) dan Return On Equity (ROE) memiliki pengaruh yang signifikan terhadap harga saham, sedangkan secara parsial (masingmasing) hanya Return On Assets (ROA) 
yang memiliki pengaruh signifikan terhadap harga saham.

Penelitian Hutami (2012), hasil penelitian menunjukkan bahwa (1) Dividend per Share berpengaruh positif dan signifikan terhadap Harga Saham Perusahaan Industri Manufaktur (2) Return on Equity berpengaruh positif dan signifikan terhadap Harga Saham Perusahaan Industri Manufaktur (3) Net Profit Margin berpengaruh positif dan signifikanterhadap Harga Saham Perusahaan Industri Manufaktur.

Penelitian Ramdhani, (2013), Berdasarkan hasil penelitian ini diketahui bahwa Return on Asset dan Debt to Equity Ratio tidak memiliki pengaruh yang signifikan terhadap Harga Saham. Hasil uji F menunjukkan bahwa Return on Asset dan Debt to Equity Ratio secara bersama-sama tidak memiliki pengaruh terhadap Harga Saham.

Penelitian Hutapea, et.al (2017), Berdasarkan hasil penelitian ini diketahui bahwa Return on Asset dan Debt to Equity Ratio tidak memiliki pengaruh yang signifikan terhadap Harga Saham. Hasil uji F menunjukkan bahwa Return on Asset dan Debt to Equity Ratio secara bersama-sama tidak memiliki pengaruh terhadap Harga Saham.

Penelitian Febrioni (2016), Jenis data yang digunakan dalam penelitian ini termasuk ke dalam jenis data sekunder berupa laporan tahunan dan laporan keuangan perusahaan sejak tahun 2011 hingga tahun 2015 yang dapat diperoleh dari website www.idx.co.id. Metode analisis dari penelitian ini menggunakan analisis regresi data panel untuk memperoleh gambaran yang menyeluruh mengenai hubungan antara variabel satu dengan variabel lainnya.

Penelitian oleh Darnita (2012), Hasil dengan menggunakan uji $F$ menunjukan bahwa kinerja perusahaan yang diukur dengan ROA, ROE, NPM dan EPS mempunyai pengaruh signifikan terhadap harga saham. Secara parsial dengan uji t disimpulkan bahwa secara parsial variabel ROA dan EPS tidak berpengaruh secara signifikan terhadap harga saham, sedangkan variabel ROE dan NPM berpengaruh signifikan terhadap harga saham.

Penelitian Tewal \& Jan 2017), Hasil penelitian menunjukkan bahwa CR, DER, ROA dan NPM secara simultan berpengaruh terhadap Harga Saham. Dan secara parsial CR dan DER tidak berpengaruh terhadap Harga Saham, sedangkan ROA dan NPM berpengaruh signifikan terhadap Harga Saham.

Penelitian Ferawati (2015), dimana dari hasil uji secara simultan (uji F), diperoleh hasil 0,000 yang berarti bahwa NPM, ROA, EPS, dan DPS secara simultan mempunyai pengaruh yang signifikan terhadap harga saham. Dengan nilai adjusted $\mathrm{R}$ square sebesar $0,732=73 \%$ yang berarti variabel bebas mampu menjelaskan variasi perubahan variabel terikat sebesar $73 \%$ dan sisanya sebesar $27 \%$ dijelaskan oleh variabel lain diluar penelitian.

\section{METODE PENELITIAN}

Metode penelitian menggunakan pendekatan kuantitatif. Metode Populasi yang digunakan dalam penelitian ini adalah perusahaan Property yang terdaftar di Bursa Efek Indonesia (BEI) pada periode tahun 2015-2018. Pengambilan sampel yang di lakukan pada penelitian menggunakan purposive sampling. Sampel pada penelitian ini dipilih berdasarkan barometer yang telah ditetapkan sebagai berikut:

1. Perusahaan Property yang terdaftar di Bursa Efek Indonesia periode. 
2. Perusahaan yang tetap dan tidak keluar dari daftar perusahaan sub sektor Property periode 2015 2018.

3. Perusahaan yang menyajikan dan mempublishkan laporan keuangan Tahunan Periode 2015 - 2018.

4. Perusahaan Yang Memiliki Laba Positif Dalam Laporan Keuangan Tahunan Periode 2015 - 2018.

Populasi dalam penelitian ini sebanyak 84 perusahaan. Sampel penelitian yang dipergunakan pada penelitan ini yaitu 43 perusahaan yang dikalikan 4 tahun dengan total data sampel sebanyak 172 sampel data. Cara pengumpulan data pada penlitian ini mempergunakan teknik studi Dokumentasi yaitu berupa data ringkasan kinerja keuangan yag telah diterbitkan di Bursa Efek Indonesia (BEI) untuk periode 2015-2018 yang diperoleh dari situs website resmi https://www.idx.co.id/, data yang dipakai adalah neraca, laporan laba rugi, dan Harga Saham. Teknik analisis yang digunakan yaitu regresi linier berganda yang terdiri dari sebuah variabel terikat yaitu Harga Saham dan tiga variabel bebas yaitu Current Ratio, Net Profit Margin, dan Return On Assets.

\section{HASIL DAN PEMBAHASAN}

Dari tabel 1, dapat disusun persamaan regresi linear berganda sebagai berikut:

$$
\mathrm{Y}=\mathrm{a}+\mathrm{b}_{1} \mathrm{X}_{1}+\mathrm{b}_{2} \mathrm{X}_{2}+\mathrm{b}_{3} \mathrm{X}_{3}+\mathrm{e}
$$$$
Y=0,357+0,104 X_{1}-0,001 X_{2}+
$$
$\mathbf{0 , 3 5 1} \mathrm{X}_{3}+\mathrm{e}$

Persamaan regresi diatas bisa dijelaskan sebagai berikut: Konstanta sebesar 0,357, artinya jika variabelvariabel independent yaitu $\mathrm{CR}\left(\mathrm{X}_{1}\right)$, $\operatorname{NPM}\left(\mathrm{X}_{2}\right)$, dan ROA $\left(\mathrm{X}_{3}\right)$ bernilai 0 , maka harga saham (Y) adalah sebesar 0,357 . Koefisien regresi variabel CR

adalah 0,104 dan bernilai positif, menunjukkan bahwa jika CR mengalami kenaikan maka harga saham akan mengalami kenaikan sebesar $0,104 \%$. Pada nilai koefisien variabel NPM adalah sebesar 0,001 dan bernilai negatif, artinya jika NPM mengalami kenaikan, maka harga saham akan mengalami penurunan sebesar $0,001 \%$. Pada koefisien variabel ROA nilainya adalah sebesar 0,351 dan bernilai positif, maka jika ROA mengalami kenaikan satu persen, maka harga saham akan mengalami peningkatan sebesar $0,351 \%$.

Tabel 1 Hasil Analisis Regresi Linear Berganda

\begin{tabular}{|c|c|c|c|c|c|c|}
\hline \multirow{3}{*}{ Model } & \multicolumn{5}{|c|}{ Coefficients $^{\mathrm{a}}$} & \multirow{3}{*}{ Sig. } \\
\hline & & \multicolumn{2}{|c|}{ Unstandardized Coefficients } & Standardized & $\mathrm{t}$ & \\
\hline & & B & Std. Error & Beta & & \\
\hline \multirow{4}{*}{1} & (Constant) & ,357 & ,036 & & 9,962 &, 000 \\
\hline & $\mathrm{CR}$ &, 104 &, 019 & 290 & 5,641 &, 000 \\
\hline & NPM &,- 001 &, 013 &,- 005 &,- 095 & ,925 \\
\hline & ROA & ,351 &, 026 & ,682 & 13,487 &, 000 \\
\hline $\begin{array}{l}\text { a. Deper } \\
\text { Sumber }\end{array}$ & $\begin{array}{l}\text { dent Variabl } \\
\text { Diolah mela }\end{array}$ & $\begin{array}{l}\text { GA_SAHAM } \\
2020\end{array}$ & & & & \\
\hline
\end{tabular}

Berdasarkan tabel 1, dapat dilihat bahwa nilai Adjust $R$ Square adalah 0,588 dan nilai $\mathrm{R}$ adalah sebesar 0,772. Pada penelitian ini dilihat berdasakan nilai Adjust $R$ Square maka berarti kemampuan variabel CR, NPM, dan ROA dalam mengelaborasi variabel harga saham adalah 58,8\% sedangkan sisanya $41,2 \%$ dipengharui oleh variabel lain yang tidak di teliti. 
Tabel 2. Hasil Uji Koefisien Determinasi $\left(\mathbf{R}^{2}\right)$

\begin{tabular}{|c|c|c|c|c|}
\hline \multicolumn{5}{|c|}{ Model Summary } \\
\hline Model & $\mathrm{R}$ & R Square & $\begin{array}{l}\text { Adjusted R } \\
\text { Square }\end{array}$ & $\begin{array}{l}\text { Std. Error of the } \\
\text { Estimate }\end{array}$ \\
\hline 1 &, $772^{\mathrm{a}}$ & ,595 & ,588 & ,04012 \\
\hline $\begin{array}{l}\text { a. Pred } \\
\text { Sumber }\end{array}$ & $\begin{array}{l}\text { Consta } \\
\text { melalui }\end{array}$ & $\begin{array}{l}\text {, ROA, C } \\
\text { ss, } 2020\end{array}$ & & \\
\hline
\end{tabular}

Pengujian hipotesis ini dilakukan untuk melihat apakah CR, NPM dan ROA berpengaruh secara serentak terhadap harga saham. Pada tabel 3, dapat dilihat nilai $F_{\text {hitung }}$ sebesar 82,429 dan nilai signifikasi adalah 0,000. Nilai $F_{\text {hitung akan dibandingkan }}$ dengan nilai $\mathrm{F}_{\text {tabel }}$ dengan rumus $F_{\text {tabel }}=$ $(k ; n-k)$. Dimana: $\mathrm{k}=$ Jumlah variabel bebas, $\mathrm{n}=$ Jumlah sampel.
Dalam penelitian ini jumlah variabel bebas berjumlah 3 dan jumlah sampel adalah sebanyak 172, maka (3; 172-3) $=(3 ; 169)$. Berdasarkan nilai distribusi pada $\mathrm{F}_{\text {tabel, ditemukan nilai }}$ sebesar 2,66 yang artinya $F_{\text {hitung }}>F_{\text {tabel }}$ $(82,429>2,66)$ dan Nilai sig $0,000<$ 0,005. Maka artinya CR, NPM dan ROA secara bersama berpengaruh secara simultan terhadap harga saham.

Tabel 3. Hasil Pengujian Hipotesis secara Simultan(Uji F)

\begin{tabular}{llrrrrr}
\hline \multicolumn{7}{c}{ ANOVA $^{\text {a }}$} \\
\hline \multicolumn{1}{l}{ Model } & Sum of Squares & Df & Mean Square & F & Sig. \\
\hline & Regression &, 398 & 3 &, 133 & 82,429 &, $000^{\text {b }}$ \\
\cline { 2 - 7 } 1 & Residual &, 270 & 168 &, 002 & & \\
\cline { 2 - 7 } & Total &, 669 & 171 & & & \\
\hline a. & Dependent Variable: HARGA_SAHAM & & & \\
b. & $\begin{array}{l}\text { Predictors: (Constant), ROA, CR, NPM } \\
\text { Sumber: Diolah melalui spss, 2020 }\end{array}$ & & & & \\
\hline
\end{tabular}

Berdasarkan tabel 3 , nilai $t_{\text {hitung }}$ akan dibandingkan dengan nilai $t_{\text {tabel }}$ menggunakan rumus $(a / 2 ; n-k-1)$. Dimana: $\mathrm{a}=$ Tingkat kepercayaan penelitian, $\mathrm{k}=$ Jumlah variabel bebas, $\mathrm{n}$ $=$ Jumlah sampel. Dalam penelitian ini jumlah variabel bebas adalah 3 dan jumlah sampel adalah sebanyak 172 , $\operatorname{maka}(0,05 / 2 ; 172-3-1)=(0,025 ; 168)$ Berdasarkan nilai distribusi pada $t_{\text {tabel, }}$ ditemukan nilai sebesar 1,974.

Nilai thitung $C R$ adalah sebesar 5,641 dan bernilai positif yang berarti $\mathrm{H}_{0}$ ditolak dan $\mathrm{H}_{\mathrm{a}}$ diterima karena thitung $>\mathrm{t}_{\text {tabel }}(5,641>1,974)$ dengan tingkat signifikan dibawah 0,05 yaitu 0,000 , maka variabel $\mathrm{CR}$ berpengaruh secara parsial terhadap variabel harga saham.

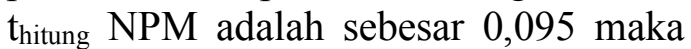
$\mathrm{H}_{0}$ diterima dan $\mathrm{H}_{\mathrm{a}}$ ditolak karena thitung $<t_{\text {tabel }}(0,095<1,974)$ dan nilai sig adalah $0,952>0,05$, maka variabel NPM tidak berpengaruh secara parsial terhadap variabel harga saham. Pada thitung ROA bernilai 13,487 maka $\mathrm{H}_{0}$ ditolak dan Ha diterima karena $t_{\text {hitung }}>$ $t_{\text {tabel }}(13,487>1,974)$ dan nilai sig adalah $0,000<0,05$, maka variabel ROA berpengaruh secara parsial terhadap variabel harga saham. 
Tabel 4 Hasil Uji Signifikan Secara Parsial (Uji-t)

\begin{tabular}{|c|c|c|c|c|c|c|}
\hline \multicolumn{7}{|c|}{ Coefficients $^{\mathrm{a}}$} \\
\hline & \multirow[t]{2}{*}{ Model } & \multicolumn{2}{|c|}{ Unstandardized Coefficients } & Standardized & $\mathrm{t}$ & Sig. \\
\hline & & $\mathrm{B}$ & Std. Error & Beta & & \\
\hline \multirow{4}{*}{1} & (Constant) & ,357 & ,036 & & 9,962 &, 000 \\
\hline & CR &, 104 & 019 & ,290 & 5,641 &, 000 \\
\hline & NPM &,- 001 & 013 &,- 005 &,- 095 & ,925 \\
\hline & ROA &, 351 & 026 & 682 & 13,487 &, 000 \\
\hline
\end{tabular}

a. Dependent Variable: HARGA_SAHAM

Sumber: Diolah melalui spss, 2020

\section{PENUTUP}

\section{Kesimpulan}

1. Hasil Uji-t pada penilitian ini menunjukkan bahwa variabel $\mathrm{CR}$ dan ROA berpengaruh secara parsial terhadap Harga Saham. Sementara variabel NPM tidak berpengaruh secara parsial terhadap Harga Saham.

2. Sedangkan secara simultan (Uji F) ketiga variabel yaitu CR, NPM, dan ROA bersama-sama berpengaruh secara positif dan signifikan terhadap harga saham.

3. Berdasarkan hasil Koefisien Determinasi yang telah di teliti, variabel CR, NPM, dan ROA dalam menjelaskan variabel Harga Saham adalah $58,8 \%$ sedangkan sisanya adalah $41,2 \%$ dipengharui oleh variabel lain yang tidak di teliti.

\section{Saran}

Berdasarkan hasil analisis linear berganda yang telah di teliti, masingmasing variabel bebas yaitu $\mathrm{CR}$ dan ROA berhubungan secara positif dalam memprediksi Harga Saham. Sedangkan variabel NPM berhubungan negatif dalam memprediksi Harga Saham. Sehingga investor harus melihat rasio keuangan lain seperti $\mathrm{CR}$ dan $\mathrm{ROA}$ yang bernilai positif dalam memprediksi harga saham jika ingin berinvestasi pada sektor Property. Berdasarkan hasil penilitian yang sudah dilakukan, maka disarankan bagi peneliti yang akan datang untuk menambah variabel bebas, jumlah emiten dan periode penelitian, serta tetap menggunakan variabel kontrol.

\section{DAFTAR PUSTAKA}

Christine, D., K. Susilawati. (2012). Analisis Perbandingan Pengaruh Likuiditas, Solvabilitas dan Profitabilitas terhadap Harga Saham Pada Perusahaan LQ 45.” (1968).

Darnita, E. (2012). Analisis Pengaruh Return On Assets (ROA), Return On Equity (ROE), Net Profit Margin (NPM) Dan Earning Per Share (EPS) terhadap Harga Saham (Studi pada Perusahaan Food dan Beverages Yang Terdaftar Di Bursa Efek Indonesia (BEI) pada Tahun 2008-2012). (Icmd).

Deitiana, T. (2013). Pengaruh Current Ratio , Return on Equity dan Total Asset Turn Over terhadap Devidend Payout Ratio dan Implikasi Pada Harga Saham Perusahaan LQ 45. Jurnal Bisnis dan Akuntansi 15(1):82-88.

Febrioni, R. (2016). Pengaruh Return on Assets, Return on Equity, Earning Per Share, dan Current Ratio terhadap Return Saham (Pada Perusahaan Yang Terdaftar di Indeks LQ45 Di Bursa Efek Indonesia Tahun 2011-2015). E-Proceeding of Management 3(3):3439-49. 
Ferawati, Y. (2015). Analisis Pengaruh Current Ratio, Net Profit Margin, Earning Per Share, dan Return on Equity Terhadap Harga Saham Perusahaan Manufaktur Sub-Sektor Makanan dan Minuman Yang Terdaftar di Bursa Efek Indonesia Periode Tahun 20122016. Implementasi Sms Geteway Untuk Layanan Informasi Absensi Siwa 01(05):1-16.

Hutami, R., P. (2012). Pengaruh Dividend Per Share, Return on Equity dan Net Profit Margin Terhadap Harga Saham Perusahaaan Industri Manufaktur Yang Tercatat di Bursa Efek Indonesia Periode 2006-2010." Nominal, Barometer Riset Akuntansi dan Manajemen 1(2).

Hutapea, A., W., Ivonne S. Saerang, \& Joy E. T. (2017). Pengaruh Return on Asset, Net Profit Margin, Debt to Equity Ratio dan Total Aset Turnover terhadap Harga Saham Industri Otomotif dan Komponen Yang terdaftar di Bursa Efek Indonesia. Jurnal EMBA 5(2):541-52.

Kurnia, N., Agung T.,A, Andi I., Y., (2018). Analisis Komparatif Metode Rasio Keuangan dan Economic Value Added Untuk Menilai Kinerja Keuangan Perusahaan (Studi Pada PT Sumber Alfaria Trijaya Tbk dan PT Indofood Sukses Makmur Tbk Yang Terdaftar di Bursa Efek Indonesia (BEI) Periode Tahun 2015-2016). Jurnal Economica 1(2):160-64.
Monterroso, S. (2015). Pengaruh Profitabilitas terhadap Harga Saham pada Perusahaan Pertambangan Batubara di Indonesia. Nhk 技 研 151(2013):10-17.

Ortecho J., Katia., F. (2011). Propuesta de Mejora En El Proceso de Distribución de Una.

Ramdhani, R. (2013). Pengaruh Return on Assets dan Debt to Equity Ratio terhadap Harga Saham Pada Institusi Finansial di Bursa Efek Indonesia. The Winners 14(1):29-39

Syaiful S, A. (2013). Pengaruh Likuiditas, Profitabilitas, Solvabilitas, dan Ukuran Perusahaan terhadap Harga Saham Perusahaan Farmasi di Bei. Jurnal Akuntansi Unesa 1(1).

Tewal, B, \& Arrazi. (2017). Pengaruh Current Ratio, Der, Roa dan Npm terhadap Harga Saham pada Perusahaan Food and Beverages Yang Terdaftar di Bei (Periode 2013-2015). Jurnal Riset Ekonomi, Manajemen, Bisnis Dan Akuntansi 5(2):1813-22. 